\title{
Keratin Biomaterials in Skin Wound Healing, an Old Player in Modern Medicine: A Mini Review
}

\author{
Marek Konop *(D), Mateusz Rybka (D) and Adrian Drapała
}

Citation: Konop, M.; Rybka, M.; Drapała, A. Keratin Biomaterials in Skin Wound Healing, an Old Player in Modern Medicine: A Mini Review. Pharmaceutics 2021, 13, 2029. https:// doi.org/10.3390/pharmaceutics13122029

Academic Editor: Luisa Coderch

Received: 27 October 2021

Accepted: 26 November 2021

Published: 28 November 2021

Publisher's Note: MDPI stays neutral with regard to jurisdictional claims in published maps and institutional affiliations.

Copyright: (c) 2021 by the authors. Licensee MDPI, Basel, Switzerland. This article is an open access article distributed under the terms and conditions of the Creative Commons Attribution (CC BY) license (https:// creativecommons.org/licenses/by/ $4.0 /)$.
Laboratory of Center for Preclinical Research, Department of Experimental Physiology and Pathophysiology, Medical University of Warsaw, 02-106 Warsaw, Poland; mateuszrybka@mp.pl (M.R.); adrapala@wum.edu.pl (A.D.)

* Correspondence: marek.konop@wum.edu.pl

\begin{abstract}
Impaired wound healing is a major medical problem. To solve it, researchers around the world have turned their attention to the use of tissue-engineered products to aid in skin regeneration in case of acute and chronic wounds. One of the primary goals of tissue engineering and regenerative medicine is to develop a matrix or scaffold system that mimics the structure and function of native tissue. Keratin biomaterials derived from wool, hair, and bristle have been the subjects of active research in the context of tissue regeneration for over a decade. Keratin derivatives, which can be either soluble or insoluble, are utilized as wound dressings since keratins are dynamically upregulated and needed in skin wound healing. Tissue biocompatibility, biodegradability, mechanical durability, and natural abundance are only a few of the keratin biomaterials' properties, making them excellent wound dressing materials to treat acute and chronic wounds. Several experimental and pre-clinical studies described the beneficial effects of the keratin-based wound dressing in faster wound healing. This review focuses exclusively on the biomedical application of a different type of keratin biomaterials as a wound dressing in pre-clinical and clinical conditions.
\end{abstract}

Keywords: keratin; keratin wound dressing; skin wound healing; tissue regeneration; regenerative medicine

\section{Introduction}

Keratin biomaterials have been in use for decades, yet they are seemingly new to the field. Keratin is a global class of biological material, which represents a group of cysteinerich filament-forming proteins [1,2]. It is the major component of hair, wool, hooves, nails, feathers, and horns are one of the most abundant and underexploited protein sources [3]. Their complex hierarchical structure, such as filament-matrix composition at nano-level and polypeptide chains, create a robust wall for protection against heat stress, pathogen invasions (particularly through the skin), and mechanical damage $[1,2,4]$. Keratins and keratinous materials are subdivided into two different classes of secondary structures of protein: alpha $(\alpha)$-keratin and beta $(\beta)$-keratin [4]. Moreover, keratins are the protein that forms a shielding layer for the epidermal appendages and, thereby, imparting an important role in protection. Keratin genes account for most of the intermediate filament genes in the human genome, making up the two largest sequence homology groups: keratins type I, also called acidic keratins; and keratins type II, called neutral-basic keratins [1,2,4].

Different keratins play different roles in the wound healing process, so it should be noted that their expression varies, depending on the stage of the wound healing process. In addition, various extraction methods allow the creation of various forms of keratin biomaterials, including films, sponges, gels hydrogels, and scaffolds [5]. Keratin materials have been extensively used in tissue engineering and regenerative medicine owing to their biological function, structural support, excellent biocompatibility, and favorable biodegradability characteristics. Accordingly, these properties allow scientists to create a new type of wound dressing that can enhance the healing process especially in chronic 
non-healing wounds [6-10]. They can be cast as sponges, films, and hydrogels for various biomedical applications [11]. In this mini review, we focused on the biomedical application of a different type of keratin biomaterials as a wound dressing in pre-clinical and clinical settings.

\section{Features of the Ideal Wound Dressing}

Impaired wound healing is a major medical problem in the modern world. Scientists around the world try to create an ideal wound dressing that could accelerate the recovery of non-healing wounds. It should be mentioned that there is no single dressing that could be used for all types of wounds. However, during tissue recovery of a single wound, different types of wound dressings could be applied. In 1989, Turner described the general criteria which an ideal dressing should possess $[12,13]$. The dressing in contact with the wound must provide a moist environment, while absorbing wound fluids [12,14,15]. It should maintain appropriate tissue temperature to improve the blood flow to the wound [16]. It should be biocompatible, biodegradable $[7,10,17]$, semi-permeable to water, and oxygen [18]. Moreover, it should promote tissue remodeling and should not provoke tissue immune responses [16]. Furthermore, changing the dressing should be painless and should not damage the newly formed tissue. It is important for the dressing to be also cost-effective [12]. In the last few years, several new dressings have been developed to improve tissue regeneration. They are indicated for specific types of chronic wounds based on a wound condition, such as being dry or exuding, superficial or deep, and clean or infected [19]. Recent progress in material sciences has been dedicated to the possibility of adding drugs, growth factors, stem cells, or silver nanoparticles into the wound dressing to improve it $[10,20-23]$. These active components should dynamically interact with the surrounding tissue and improve healing either by helping the removal of necrotic tissues or preventing secondary infections $[12,24]$. It has to be pointed out that wound dressings containing antibiotics are valuable in the management of local (where the highest concentrations of applied antibiotics are required), but not systemic, infections. Nevertheless, in some cases, high amounts of antibiotics or nanoparticles can lead to systemic toxicity and impaired wound healing $[12,23,25]$.

\section{Structure and Function of the Skin}

Skin is the biggest human complex and multifunctional organ; see Figure 1. It carries out many vital functions, including protection against external physical, chemical, and biological agents.

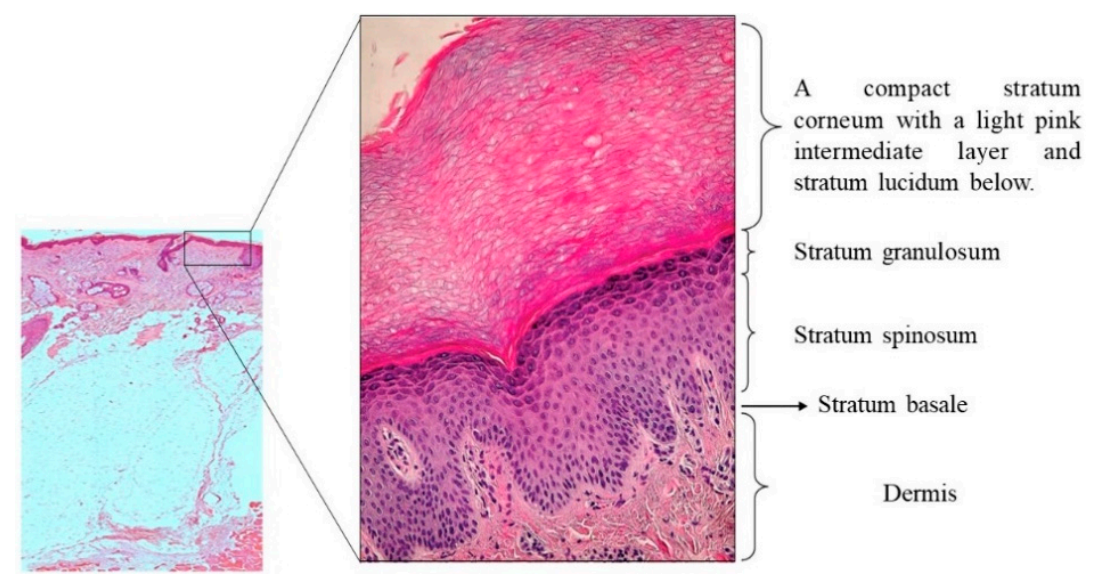

Figure 1. Structure of the skin end epidermis (courtesy of J. Czuwara, MD, Ph.D.). Magnification $200 \times$ (online, in color; black and white, in print).

By the same token, it prevents excess water loss from the body and participates in the thermoregulation process. From a histological point of view, it consists of two 
layers, the epidermis, and dermis, separated by a basement membrane zone $[26,27]$ and subcutaneous tissues.

\subsection{Epidermis}

The epidermis is the outer layer of the skin and constitutes a barrier that denies the entry of pathogens and foreign bodies to the body. By the way, it protects the body from DNA damage caused by ultraviolet (UV) radiation and retains water [28-30]. In 95\%, it consists of keratinocytes, followed by melanocytes, Langerhans cells, and Merkle cells. These cells represent $5 \%$ of the total cells existing in this layer. A keratinocyte is a cell that manufactures and stores the protein called keratin. The epidermis consists of four layers: stratum basale, stratum spinosum, stratum granulosum, and stratum corneum, depending on the state of keratinocyte differentiation [27,31]. The epidermis is a continually renewing skin layer and gives rise to derivative structures, such as hair and nails. The full regeneration process takes about $40-48$ days [27-29,31].

\subsection{Basement Membrane Zone (BMZ)}

Basement membrane zone (BMZ) is histologically defined by a $0.5-1.0 \mathrm{~mm}$-thick bandlike structure that separated the epidermis from the dermis [32]. It is a complex, precisely organized, and dynamic collection of proteins that provide structure and regulate cell adhesion, differentiation, motility, signal transmission, and membrane permeability. This skin region consists of an intricate network of macromolecules that link the keratin intermediate filaments of basal keratinocytes with collagen fibers in the superficial dermis [33]. The main function of the proteins and glycoproteins within the BMZ is to provide adhesion between the epidermis and the dermis [34,35].

Any abnormalities or defects observed in these molecules result in skin blistering diseases, such as pemphigoid and pemphigus diseases. The pemphigoid group is characterized by autoantibody-mediated inflammation at the dermal-epidermal junction (DEJ) with autoantibodies against components of the BMZ (Figure 2) [36,37]. The pemphigus group is characterized by the loss of connection between keratinocytes and cells of the epidermal spinosum (stratum spinosum) through the loss of intercellular bridges [38].
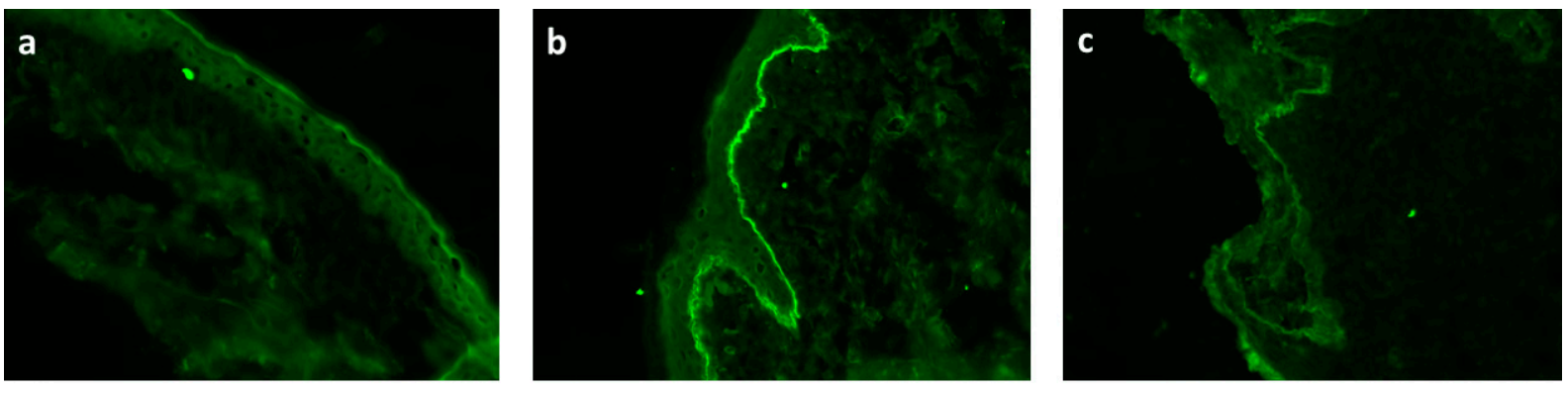

Figure 2. Direct immunofluorescence of skin biopsy in patients with bullous pemphigoid disease (a) control skin, (b) positive staining for BMZ in the skin, (c) positive staining for BMZ in mucosa membrane). Magnification $200 \times$ (private photography) (online, in color; black and white, in print).

Despite everything, direct immunofluorescence examination does not distinguish $\mathrm{BP}$ from EBA, and the salt-split skin technique is necessary to distinguish EBA from BP (Figure 3). 

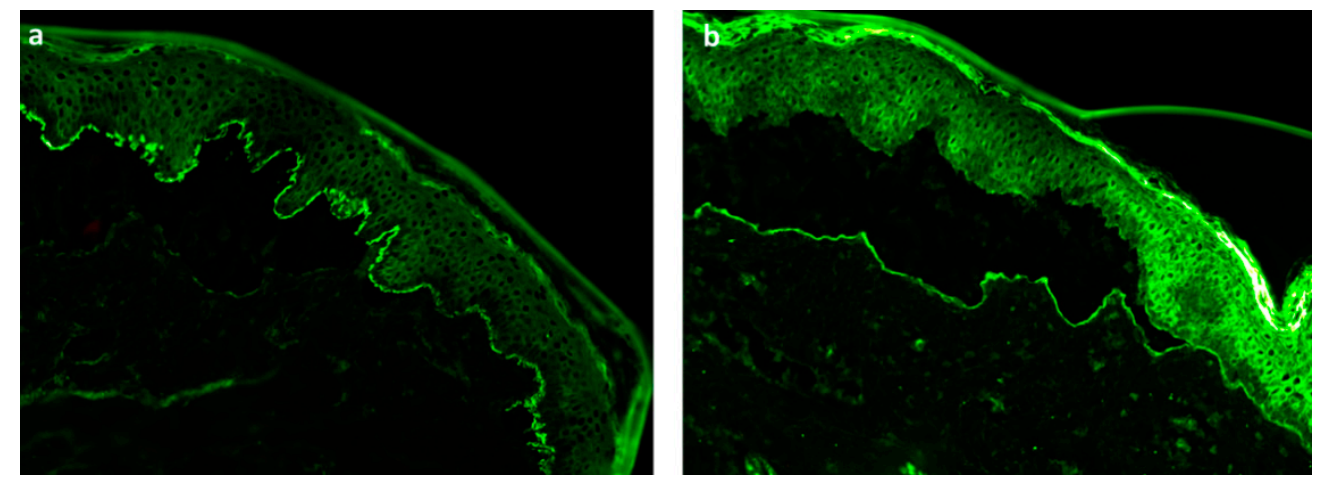

Figure 3. The salt-split skin technique is used to distinguish BP from EBA: (a) roof staining in bullous pemphigoid, (b) flor staining in epidermolysis bullosa acquisita. Magnification $200 \times$ (private photography) (online, in color; black and white, in print).

\subsection{Dermis and Subcutaneous Tissues}

The dermis is 0.5 to $5 \mathrm{~mm}$ thick, depending on the body site (thinnest on the eyelid, much thicker on the sole), and it is composed of extracellular matrix (ECM) components such as collagen, elastin, and glycosaminoglycans, with fibroblasts being the primary cell type. It is highly vascularized and is inhabited by dermal adipose cells, mast cells, and infiltrating leukocytes [39]. This skin layer could be divided into the papillary dermis (PD) and reticular dermis (RD) [40,41]. Collagen and elastic fibers are deposited by fibroblasts. In the dermis layer, we can find also histiocytes, antigen-presenting cells that phagocytose and degrade foreign substances and present antigens to T cells. These cells are responsible for the debridement of tissue through eating bacteria and dead cells, as well as tissue fragments, and foreign bodies. About $70 \%$ of the dry weight of the epidermis is made up of collagens, of which the predominant types are types I and III [30,41,42].

Directly below the dermis is where the subcutaneous layer is located, which connects the skin to the underlying fascia (fibrous tissue) of the bones and muscles. The thickness depends on the skin site, sex, and an individual's nutritional habits. In the subcutis, the adipocytes are organized into lobules that are separated by septae of connective tissue. The adipose tissue has metabolic functions: it is responsible for the production of vitamin D and triglycerides [39].

\section{Role of Keratin in Wound Healing}

Keratins can be categorized as soft or hard keratins, depending on the tissue types in which they are expressed. The epithelial keratins (soft keratins) are found in the epidermis, oral mucosa, and other epithelial linings. They form intracellular intermediate filament networks which provide a scaffold for epithelial cells and tissues to withstand mechanical stress and maintain structural integrity. They are also involved in cell physiology processes, such as cell adhesion, migration, and differentiation [43]. Keratins accomplish these functions by interacting with a myriad of signaling proteins. Frequently, these interactions are mediated by elaborate post-translational modifications of keratins [44].

Apart from epithelial keratins, trichocytic keratins (or hard keratins) are found in epidermal appendages and are further classified into $\alpha$-keratins (found in hair or wool) and $\beta$-keratins (found in avian feathers and reptilian tissues) [45]. Moreover, comparisons between the amino acids sequence of trichocytic $\alpha$-keratins (e.g., sheep's wool) and the epithelial cytokeratins showed that they are homologous in the $\alpha$-helical rod domain, but they differ considerably in the head and tail domains. During development, the hair follicle germ-cells derive from the fetal epidermis. Therefore, it is important to establish whether the expression of epidermal-type cytokeratins is continued in the cells of the bulbar follicular base that are involved in hair formation [46]. It should be mentioned that hard keratins are a distinct sub-family of keratins having a higher sulfur content due to a larger proportion of cysteine residues in their primary sequences [43,45-47]. 
Keratins are responsible for the organized proliferation of the keratinocytes and maintaining their integrity in the epithelium. Keratins are the intermediate-filamentforming proteins expressed in epithelial cells and can be divided into two groups: keratins type I, also called acidic keratins (KRT9-KRT40); and keratins type II, called neutral-basic keratins (KRT1-KRT8) [48,49].

Both types of keratins are produced by activated keratinocytes. They are encoded by 54 evolutionarily conserved genes (28 types I, 26 types II) and regulated in a pairwise and tissue type-, differentiation-, and context-dependent manner [48,49]. In vivo keratins always exist as heteropolymers containing one type I and one type II keratin. The expression of different pairs of these keratin monomers varies from layer to layer, depending on the level of the dermis. For example, the biggest expression of KRT14-KRT5 occurs in basal layers of keratins, while a large amount of KRT10-KRT1 is present in suprabasal levels of the epidermis [50]. It should be mentioned that keratins are involved in intracellular signaling pathways, e.g., protection from stress, apoptosis, and wound healing (Figure 4) [44,49].

a) Cell growth.

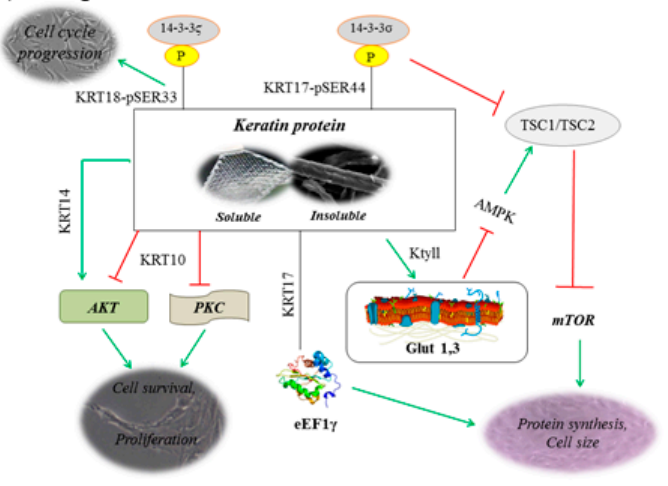

c) Cell survival and cell death.

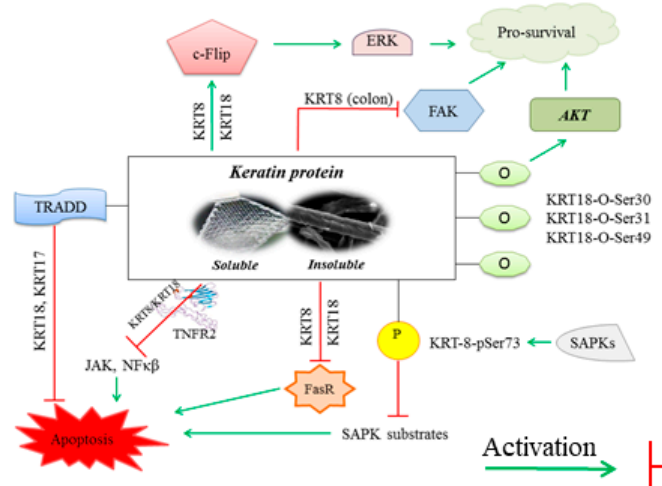

b) Cell motility and related processes.

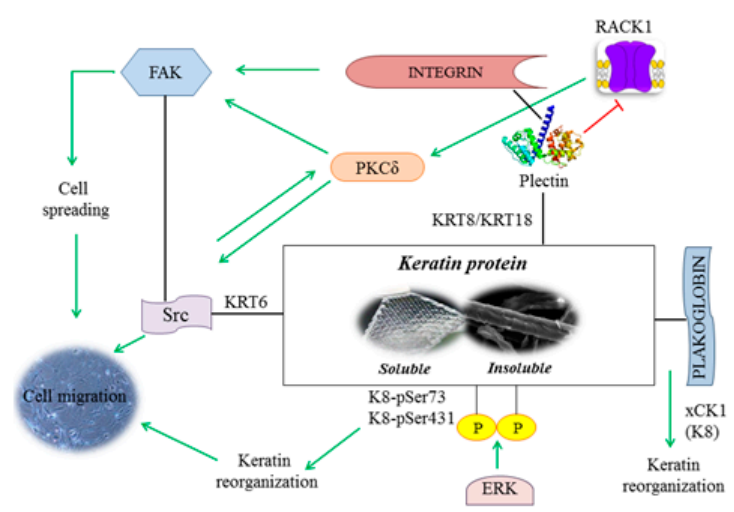

Abbreviations: Akt, Protein kinase B; AMPK, AMP-activated protein kinase; eEF1 $\gamma$, Eukaryotic translation elongation factor 1 gamma; ERK, Extracellular signal-regulated kinase; FAK, Focaladhesion kinase-1; FasR, Fas-ligand receptor; Glut1, 3, glucose transporters 1, 3; $\mathrm{K}$, mammalian keratins; KtyII, Type II mammalian keratins; mTOR, Mammalian target of rapamycin; PKC, protein kinase C; RACK1, Receptor for activated protein kinase C; SAPK, stress activated protein kinases; Src, Src kinase; TNFR2, Tumor necrosis factor receptor 2; TRADD, Tumor necrosis factor receptor type I-associated Death domain protein; TSC1/2, Tuberous Sclerosis Complex (Hamartin/Tuberin); $\mathrm{xCK}$, Xenopus cytokeratin (ortholog to mammalian K18).

Lines connecting keratins and the molecule(s) of interest indicate physical interaction

Figure 4. Keratin proteins regulate and participate in different cellular and physiological processes (online, in color; black and white, in print).

The most important keratins involved in wound healing are KRT16/KRT17-KRT6. During the first hours after wounding, KRT16/KRT17-KRT6 is being highly expressed, at the cost of KRT10-KRT1, which makes it easier to promote proliferation over differentiation [51].

Studies achieved using the null-mice, allowed researchers to discover the function of keratins in the wound healing process. Mice with KRT6a and KRT6b deletions had not shown any pathological symptoms at birth, but, after a few weeks, they died due to massive oral epithelium blisters, followed by poor nutrition [52]. Although, when KRT6a/KRT6b null skin was grafted into healthy mice, this fragment was more fragile to damage. Besides that, lysis of keratinocytes and swelling was noted. In an ex vivo KRT6a/KRT6b null skin fragment, there was a decreased concentration of KRT16, even despite normal KRT16 mRNA levels. Due to this fact, it is believed that KRT6 is needed to support the stability 
of KRT16, which in vivo creates KRT6/KRT16 heteropolymers [53]. On top of that, KRT6 directly interacts with SRC kinase, decreasing its activity, which weakens cell migration in wounded skin. Migrating cells lacking KRT6a/KRT6b proteins showed significantly decreased cell-cell adhesion, usually leaving gaps between cells. In contrast, healthy cells from the control group made organized structures after cell migration [53,54].

Keratin-17 (KRT-17) is responsible for keratinocyte proliferation. KRT-17 null keratinocytes are smaller, have decreased speed of protein translation associated with decreased mTOR/AKT signal, which has a direct impact on keratinocytes proliferation [55]. Another role of KRT-17 is to support the phosphorylation of STAT3 and the transportation of this protein to the cell nucleus. This increases translation of D1 cyclin that is necessary for the proper proliferation of keratinocytes [56].

In acute wounds, keratinocytes migrate from the wound margins, proliferating and releasing cytokines to initiate tissue response. However, impaired wound healing a special in diabetes can cause chronic wounds, such as ulcers, where keratinocytes appear to be unable to migrate, leaving this phase of wound healing incomplete [57].

It should be mentioned that some classes of keratin exhibit characteristic expression patterns in human tumors. Some of them, especially K5, K7, K8/K18, K19, and K20, have great importance in immunohistochemical diagnosis, particularly of unclear metastases and precise classification, as well as subtyping of carcinomas [58].

\section{Biomedical Properties of Keratin}

Many scientific groups around the world look for new therapies, regeneration methods, which are based on the use of natural-derived biomaterials that can support wound healing. Knowing the physicochemical and biological properties of different biomaterials, we can create a new material that can be used for biomedical applications, including wound dressing or drug delivery systems [59]. In this context, keratin biomaterials possess a unique set of properties, such as excellent biocompatibility, biodegradability, and bioactivity. They also possess a hydrophilic surface, which is absent in many synthetic polymers [60]. To appropriate understanding and use the following terms: biocompatibility, biodegradability, and bioactivity term, it is necessary to introduce basic definitions of them.

Biocompatibility can be defined as the ability of materials to interact with host cells without causing systematic and local cytotoxicity, mutagenesis, carcinogenicity, allergic reactions, or inflammation [61]. Several in vitro studies on different cell lines have been shown that keratin biomaterials are biocompatible and support cell growth [62-64]. Yamauchi et al. [65] proposed that keratin-coated substrate has shown better L929 fibroblasts attachment and growth compared to the ones coated with collagen. Park et al. [66] have also reported that keratin extracted from human hair is more effective in healing wounds due to the almost complete regeneration of epithelial cells. Sadeghi et al. [67] examined carboxymethyl cellulose (CMC)-human hair keratin hydrogel with controlled clindamycin in vitro on mouse fibroblasts. They showed that increasing the content of keratin in CMC hydrogel not only lowered water vapor transmission rate to a suitable range for wound healing but also improved the water stability of CMC hydrogel. The in vitro release study indicated that clindamycin was released slower in samples containing higher keratin. Higher keratin content led to better cellular attachment, proliferation, and spreading. Summarizing, the addition of keratin into the carboxymethyl cellulose improves their properties compared with pure CMC samples.

Another important parameter described biomaterials in the field of tissue engineering and regenerative medicine is bioactivity. Bioactivity is closely related to biocompatibility and can be broadly defined as "one which has been designed to induce specific biological activity" [68]. Biodegradability is an essential property for designing biomaterials used in tissue engineer and regenerative medicine. Despite this, a typical scaffold should have similar mechanical properties to the host tissue. Biodegradability can be defined as the ability of a material to break down into its simpler components after contact with the biological environment after implantation [69]. The in vivo biodegradation of keratin was 
explored by the different research groups. Peplow et al. [70] examined wool keratin bars after subcutaneously implanted into adult rats for 18 weeks. They found that this gradual degradation and quick loss of mechanical integrity showed that this form of keratin is more appropriated as a resorbable implant material to provide a scaffolding framework for cell migration and proliferation. In another study, Bochyńska-Czyż et al. [64] examined in vitro keratin scaffolds derived from rat fur. They showed that co-cultures of rat mesenchymal stem cells on keratin biomaterial confirm the formation of 3D cell culturing on keratin scaffolds and can be maintained in vitro for several weeks without morphological changes of cells. This observation confirms good biocompatibility, low immunogenicity, and slow biodegradation of keratin biomaterials.

Apart from this, keratin biomaterials derived from wool and hair have shown the capability to support cellular attachment as they possess cell-binding motifs, such as glutamic acid-aspartic acid-serine (EDS), arginine-glycine-aspartic acid (RGD), and leucineaspartic acid-valine (LDV) binding residues [22,71]. The presence of LDV and EDS binding residues support cellular attachment, while RGD acts as a binding motif for proteins, such as fibronectin, fibrinogen, and osteopontin [22,72].

\section{Antibacterial Properties of Keratin Biomaterials}

Antimicrobial efficacy is one of the most important requirements for modern scaffolds for wound care, tissue engineering, and biomedical applications as a whole [73]. It should be mentioned that keratin itself exhibits antimicrobial activity, although it is not outstanding compared to the activity of silver nanoparticles, it is significant. This may be attributed to some important functional groups present in keratin protein, especially in the peptide backbone, such as disulfide (-S-S), amino acid (-NH2), and carboxylic acid (-COOH). Amino acid analysis shows that keratin has a high content of cysteine residues (7-20\% of all amino acid residues). Thus, it appears that the binding of the positively charged amino groups of keratin and the negatively charged bacterial cell wall causes keratin to inhibit bacterial growth [73].

Regardless of the source of keratin (hair, fur, or feathers), the materials exhibit antimicrobial properties which can be enhanced by the addition of antimicrobial substances or drugs (e.g., AgNP or mupirocin) [10,74]. Konop et al. [7,10] showed that insoluble fraction of keratin scaffolds alone or with the addition of silver nanoparticles exhibit antimicrobial properties against S. aureus and E. coli in vitro. Moreover, they do not observe the sign of bacterial infection in keratin-treated wounds in diabetic mice. In addition, another group showed that keratin biomaterial alone or mixed with antibacterial agents possess antimicrobial properties.

He et al. [75] showed that the AgNPs-embedded FK/PVA/PEO nanofibers exhibited antibacterial activities against both Gram-positive (S. aureus) and Gram-negative (E. coli) bacteria. A clearer and larger circular inhibition zone were observed against $E$. coli compared with S. aureus. In another study, Amajuoyi et al. [75] examined keratin/coenzyme Q10/polyvinyl alcohol nanofibrous scaffold containing mupirocin and showed that obtained biomaterial possess excellent antimicrobial activity against all clinical isolates strains of Staphylococcus aureus. Sundaram et al. [76] examined the antimicrobial properties of keratin nanoparticles made from chicken feathers. They showed that the zone of inhibition was higher for $S$. aureus compared with E. coli $(11 \mathrm{~mm}$ vs. $9.5 \mathrm{~mm})$, which indicates that the obtained keratin nanoparticles can be effective against infections caused by bacteria.

On the other hand, single reports suggest that bacteria presenting keratinolytic properties may grow more likely in the environment enriched in specific keratin proteins. Nasipuri et al. [11] showed that four bacterial strains (S. rhizophila, X. retroflexus, M. oxydans, and P. amylolyticus) isolated from solid can degrade the keratin. X. retroflexus was the best keratin degrader in terms of culture density and keratin degradation, as well as combined with the non-degraders M. oxydans and P. amylolyticus, and/or S. rhizophila that did degrade keratin but grew slowly, to investigate community degradation as compared to single species. 
Summarizing, independently from keratin source, the obtained biomaterials possess antimicrobial properties, are safe, and can be considered as a new type of wound dressing a specially in the case of chronic, non-healing wounds burdened with a bacterial infection.

\section{Effect of Keratin on Hyperpigmentation}

There is a growing list of keratin-related genetic diseases that point to new functions for keratin. One of these functions is a role in skin pigmentation. Some of the key supporting evidence comes from studies of unconventional forms of epidermolysis bullosa simplex (EBS) and other disorders resulting from KRT5 or KRT14 mutations [77,78]. Uttam et al. [79] found out that a peculiar missense mutation, Pro24 $\rightarrow$ Leu, in the head domain of KRT5, causes EBS with mottled pigmentation, in which small (2- to 5-mm wide) hypo- or hyperpigmented spots confer a mottled appearance to the skin. Moreover, Betz et al. [80] have linked Dowling-Degos disease (DDD), which is characterized by reticulate hyperpigmentation and dark hyperkeratotic papules in skin flexural regions, to KRT5 haploinsufficiency. Further, dermatopathia pigmentosa reticularis (DPR) and Naegeli-Franceschetti-Jadassohn syndrome (NFJS) are two related dominantly inherited conditions featuring reticulate or mottled hyperpigmentation of the skin that are caused by frameshift mutations, which are located in the head domain of KRT14 [81].

Evidence supporting a novel role for keratin proteins in regulating skin pigmentation also comes from genetic animal models, primarily in mice. It is associated with mutations within the genes for KRT1, KRT2, and KRT4 [77,78]. Fitch et al. [82] used random chemical mutagenesis to identify genes involved in fur color determination in mice. Of the genes identified, dominant missense alleles in KRT2e (T500P) [82] or KRT1 (S194P) [83]. A third mutation, N154S, was found in the KRT4 gene in a mouse line showing a lighter than normal fur color [84]. It should be highlighted that the KRT4-KRT13 keratin pair is predominantly expressed in the stratified epithelial lining of the oral mucosa and esophagus [85]. In humans, mutations in KRT4 or KRT13 cause oral white sponge naevus (WSN), a rare condition primarily affecting the oral mucosa [86].

Loan et al. [87] presented a cohort study in which wounds of 40 patients who suffered from superficial and partial-thickness burns were observed and rated from 1 (normal skin) to 10 (worst scar imaginable), depending on a change of skin pigmentation in the wound area after using keratin-based treatment. Twelve months after keratin-based treatment, the skin was normally pigmentated in $73 \%$ of all patients, $20 \%$ of them were given 2 or 3 points, and only $7 \%$ were given $>3$ points. However, since there was no control group in this study, and hyperpigmentation after partial-thickness burn is being described regardless of the treatment method [88], further studies should be executed to evaluate the impact of keratin-based treatment on hyperpigmentation.

To summarize, there are reports of keratin expression in melanocytes, the significance of which remains unclear [89]. In-depth studies of how keratin proteins may be regulating melanosome import, as well as melanin distribution, will help characterize this newly emerging role of cytoplasmic keratin intermediate filaments.

\section{Biomedical Propertied of Keratin Biomaterials}

During the last few years, a lot of effort has been devoted to the development of functional wound care products which, apart from antimicrobial protection, contain ingredients that promote wound healing [90]. In this context, keratin biomaterials increased scientists attention due to excellent biocompatibility and the possible preparation of different forms of a wound dressing. Keratin biomaterials can occur in the form of gel, hydrogel, foam, films, and scaffolds [11]. A different form of keratin has been studied for its application as promising biomaterials for wound healing, bone regeneration, hemostasis, and peripheral nerve repair. It should be mentioned that lots of studies describe the application of a soluble fraction of keratin as a wound dressing [3,91,92]. However, in the literature, we can find only a few studies that described the insoluble fractions of keratins in wound treatment $[7,10,93]$. Moreover, the basic wound dressing can be modified with antimicrobial 
compounds, such as silver nanoparticles (AgNP), antibiotics, or other substances, that can improve the recovery of injured tissues and prevent secondary infection $[10,23]$.

Regardless of the form in which it occurs, the dressings are tested on different wound healing models in laboratory animals. Chronic, non-healing wounds are a serious problem for people suffering from diabetes. Therefore, different scientific groups examined potential keratin-based dressings in healthy and diabetic conditions that can occur in laboratory conditions. In addition, single experimental studies described the application of keratin gel as a wound dressing in a patient with bullous diseases.

Lin et al. [22] examined keratin biomaterial extracted from human hair in vitro and in vivo. They showed that the obtained biomaterial is biodegradable, biocompatible, and supported human adipose stem cells (hASCs) adhesion, proliferation, and differentiation. In vivo investigation performed on ICR mice showed that keratin scaffolds with hASCs shortened healing time accelerated epithelialization and promoted wound remodeling in comparison with the keratin-scaffolds-only group, hASCs-only group, and control. On the whole, keratin scaffolds possess appropriate pore size and good cytocompatibility and can be further applied in the field of regenerative medicine.

In the other study, Kim et al. [94] analyzed the opportunity to use keratin hydrogel made of human hair in the full thickness mouse excisional wound splinting model. Twenty-one days after wounding, they observed that, in keratin-hydrogel-treated mice, skin was fully recovered without any sign of scab and wound contraction, while, on the control side, scabbing was still visible. Histopathological examination showed that the rates of re-epithelialization, remodeling, and repair in the keratin-based hydrogel-treated group were 2-fold higher than those of the negative control group, which were calculated as $50,37.5$, and $12.5 \%$ in the negative control group, and as 20,50 , and $30 \%$ in the keratin-treated group. Subsequent studies, carried out by Li et al. [95], examined the influence of keratin hydrogel with the addition of insulin in full-thickness skin wound healing, scar creation, and hemostasis in Sprague Dawley rats. Rats were separated into four groups: control, keratin-treated, insulin-treated, and insulin-keratin-treated group (Ins-K). In the Ins-K hydrogel-treated group, higher hemostatic abilities were noted, compared to the keratin group. They observed that, between all of the groups, the fastest wound closure appeared in the Ins-K-treated group in the early stage of regeneration (first 2 weeks, $p<0.05)$. Another important fact is that wounds treated with Ins-K hydrogel have a more regular arrangement of the tissue and present the lowest TGF- $\beta$ levels, which caused the inhibition of the fibroblast cells hyperplasia, and prevented the wound from scarring. Summarizing, the obtained results established that keratin possesses the abilities of hemostasis, wound healing, and scar inhibition after insulin conjugation and can be used as a safe wound dressing.

Poranki et al. [96] examined keratin-hydrogel prepared from human hair, on skin regeneration after chemical and thermal burns in mice and swine. The in vitro thermal injury studies showed that gamma-keratose-treated fibroblasts did not show decreased cell viability at $24 \mathrm{~h}$, characteristic for other experimental groups (crude and gamma keratose). Gamma-keratose-treated fibroblasts were able to increase cell viability to $125 \%$, at the same point of the experiment, where alpha keratose grew to $46 \%$, and crude keratose grew to $65 \%$. In vivo studies performed on mice and swine set out that wounds treated with keratose hydrogel showed significantly faster wound closure, with complete wound closure within 18 days compared to 24 days in chitosan and saline-treated wound. This study showed that the gamma fraction, composed essentially of degraded alpha keratin proteins, may facilitate cell rescue after thermal injury. Treatment of burns with this type of keratin protein may, therefore, represent a potential therapy in the treatment of burn wounds in the future.

Gao et al. [97] investigated the wound healing ability of the recombinant human hair keratin proteins (RKNP37 and RKNP81) and keratin nanoparticles (KNP) in a fullthickness wound model in SD rats. In vitro studies performed on HaCaT keratinocytes showed significantly increased cell proliferation and migration in a dose-dependent manner 
compared to control. RKNP37 and RKNP81 in the concentration of $1.000 \mathrm{mg} / \mathrm{mL}$ showed increased cell growth of $250 \%$ and $310 \%$, respectively, compared to the concentration of $0.000 \mathrm{mg} / \mathrm{mL}$. They observed that the RKNP81 displayed a stronger cell proliferation ability than RKNP37. Open-excision full-thickness wounds were created on the rat's dorsum and covered with $0.500 \mathrm{mg}$ of RKNP37, RKNP81, or KNPs and fixed with Tegaderm film. A wound covered with Tegaderm film serves as a control. In vivo experiments showed that KNPs and the RKNPs significantly accelerate wound healing within 2 weeks, and the RKNPs displayed a stronger wound-healing ability than KNPs. In addition, wounds treated with RKNP81 revealed a stronger wound-healing effect compared to RKNP37. To summarize, the RKNP's treatment of dermal wounds resulted in improved epithelialization, vascularization, collagen deposition, and remodeling. The in vivo biocompatibility test revealed no systemic toxicity. This biomaterial did not induce tissue inflammation nor immune responses that were biocompatible and biodegradable.

Since radiotherapy combined with surgery is a common therapy in malignant tumor therapy, Chen et. al. [98] examined hydrogels containing keratin extracted from the human hair, as a potential biomaterial useful in the treatment of irradiated full-thickness skin wounds. In vitro studies performed on $\mathrm{HaCaT}$ keratinocytes irradiated with $5 \mathrm{~Gy}$ of gamma radiation showed that, after $48 \mathrm{~h}$, cell viability was significantly higher $(p<0.01)$ in the keratin irradiated $(\mathrm{K}+\mathrm{IR})$ group $(\sim 120 \%)$ compared to the non-keratin irradiated (IR) group $(\sim 60 \%)$. In vivo studies consisted of two stages: rats were exposed to 5 Gy of gamma radiation, and then a surgical procedure was performed. In keratin hydrogeltreated wounds, the faster repair was observed when compared to other groups. It has also been observed that irradiated keratin-treated wounds showed a regular reduction of wound area every 7 days until the full closure. It was further noted that irradiated wounds without hydrogel treatment were only marginally healed.

Konop et al. [8] examined insoluble keratin dressing named fur keratin-derived protein (FKDP) in a full-thickness skin wound model in healthy mice. They showed keratin biomaterial is not only toxic to the NIH/3T3 cell line but also enhances cell proliferation compared with the control $(p<0.05)$. In vivo studies have shown that keratin dressing is tissue biocompatible and accelerates epithelialization compared to the control side. It should be mentioned that FKDP-traded wounds healed faster on day $5(p<0.05)$ in comparison to control wounds. They also pointed out that, in FKDP-treated wounds, predominant macrophages and the epidermis were thicker. The presence of the mentioned cells creates a more favorable environment for healing. They also argued that keratin dressing favors the reconstruction of a more regular skin structure and assures a better cosmetic effect in terms of scar formation and appearance.

Shanmugasundaram et al. [99] describe the application of nonwoven wound dressings made from chicken feather keratin (CFK-NW), keratin-sodium alginate (CFK-SA-NW), and keratin-chitosan (CFK-CS-NW) in a partial thickness skin wound in Wistar rats. Antimicrobial studies confirmed a positive antibacterial effect against $S$. aureus, K. pneumoniae, and E. coli bacteria. In vitro examination on L929 mouse fibroblast showed that all obtained keratin biomaterials are non-toxic and support cell viability. It was shown that wounds treated with CFK-CS-NW and CFK-SA-NW dressings heal faster compared to wounds treated with CFK-NW and untreated control.

Vakilian et al. [100] proposed a new type of keratin biomaterial derived from the shed skin of two different Omani snakes (Puff and Cat Snakes) as a wound dressing in full-thickness skin wound healing in Wistar rats. Rats were divided into 4 groups: group 1, positive control (PC) treated with Solcoseryl ointment, group 2 where wounds were covered with Puff snake shed skin (P), group 3 with wounds covered with Cat snake shed skin (C), and group 4 which served as a negative control, i.e., without any treatment. Animal studies showed that skin reconstruction was effectively improved under P shed skin treatment when compared with the negative and positive control (PC) and C-treated groups. Moreover, the authors suggest that P snake shed skin might heal acute wounds 
either directly or indirectly via the release of inflammatory cytokines and granulation tissue formation, resulting in reepithelization, neovascularization, and fibroblast expansion.

\section{Diabetic Condition}

Impaired wound healing is a medical problem, especially in patients with diabetes. Many scientists have looked for new therapeutic strategies in the field of chronic nonhealing wounds. In this case, naturally derived biomaterials, such as keratin, are promising agents which can be used in the future as a wound dressing.

Veerasubramanian et al. [101] tested hydrogel composed of konjac glucomannan (KGM), human hair proteins (KER), and an ethanolic extract of Avena sativa (OAT) as a potential biomaterial for diabetic wounds in rats. The in vitro examination showed that the obtained hydrogel is biocompatible, non-toxic for the NIH/3T3 cells, and possesses antimicrobial activity against $S$. aureus and $E$. coli. Wounds treated with hydrogels $($ KGM + KER + OAT) undergo faster re-epithelialization, and a thick epithelial layer and matured collagen were visible on day 12. Masson-trichome staining showed that the $\mathrm{KGM}+\mathrm{KER}+\mathrm{OAT}$ scaffold aids collagen synthesis and deposition, which leads to accelerated wound healing in diabetic rats. Complete wound closure was observed on day 16 in the test group treated with KGM + KER + OAT compared with KGM + KER dressings and the control, respectively (day 20 and 24 post-injury).

Ponrasu et al. [102] investigated hydrogel scaffolds composed of morin, psyllium, and keratin (PSH + KER + MOR) as a potential biomaterial that supports skin wound healing in diabetic Wistar rats. They noted that, cell viability was similar (around 82\%) in all three groups: PSH + KER, PSH +KER + 0.5\% MOR, and PSH + KER + 1\% MOR after 48-h observation. Antimicrobial studies showed that MOR scaffolds had a bacteriostatic effect against $S$. aureus. On the other hand, PSH + KER hydrogels showed poor properties against gram-negative bacteria (E. coli). In vivo wound healing process in diabetic rats was observed in every 4-day interval. Animal studies showed that PSH + KER + MOR scaffold treatment significantly reduced the re-epithelialization time and enhanced the rate of wound contraction by accelerating collagen synthesis in diabetic rats compared to controls.

Konop et al. [7] tried to determine the possible application of an insoluble fraction of fur-derived keratin biomaterial as a wound dressing in a full-thickness surgical skin wound model in diabetic mice. They showed that keratin dressing significantly $(p<0.05)$ accelerated healing during the first week after surgery compared to control wounds. The dressings were incorporated naturally into granulation and regenerating tissue without any visible signs of the inflammatory response, which was confirmed by clinical and histopathological analysis. Therefore, it can be considered a safe and efficient wound dressing.

To improve antimicrobial properties, the obtained keratin dressing can be supplemented with various antimicrobial agents. Konop et al. [10] modified basic keratin dressing with silver nanoparticles and evaluated it in a full-thickness skin wound model in diabetic mice. Microbiologic results revealed that the insoluble FKDP-AgNP dressing, to some extent, contributed to inhibit growth of E. coli and S. aureus. In vitro assays showed that the FKDP-AgNP dressing did not inhibit fibroblast growth nor induce hemolysis and was biocompatible properties. FKDP-AgNP significantly accelerated wound closure and epithelization at days 5 and $8(p<0.05)$ when compared with control wounds. Histological examination of the inflammatory response documented that FKDP-AgNP-treated wounds contained predominantly macrophages, while their untreated variants showed mixed cell infiltrates rich in neutrophils. Wound inflammatory response based on macrophages favors tissue remodeling and healing.

In a subsequent study, Konop et al. [93] modified keratin biomaterial (base dressing FKDP) with opioid peptide-casomorphin and examined in vitro and in vivo in diabetic mice model of full-thickness wound model. They showed that casomorphin slowly releases from the wound dressing. They pointed out that keratin-casomorphin dressing is biocompatible, non-toxic, and supports cell growth. In vivo experiments demonstrated 
that keratin-casomorphin dressing significantly $(p<0.05)$ accelerates the whole process of skin wound healing to its final stage. Wounds covered with keratin-casomorphin dressing underwent reepithelization faster, ending up with a thicker epidermis than control wounds. They showed that applied keratin dressing favored reconstruction of more regular skin structure and assured better cosmetic outcomes in terms of scar formation and appearance. Furthermore, obtained wound dressing created a favorable microenvironment and supports skin wound healing in diabetic mice.

All studies performed by Konop et al. [7,8,10,93] showed the possibility of applying an insoluble fraction of keratin biomaterial as a wound dressing. Moreover, due to heterogeneous surfaces, it is possible to incorporate compounds with antimicrobial or analgesic properties. However, the authors should perform future studies that are needed to explain the molecular mechanism behind the fur-derived keratin effect during the multilayer wound healing process. Their findings may open the way for a new class of insoluble fur keratin dressings in chronic difficult-to-heal wounds treatment.

All mentioned studies have shown that, regardless of the source of keratin (hair, fur, feather chicken, or shed snakeskin), the obtained biomaterial is tissue biocompatible and supports cell growth in vitro. Experimental studies in healthy and diabetic animals showed that keratin-treated wounds healed significantly faster compared to control wounds (Table 1) and underwent faster reepithelization with minimal scar formation. Moreover, examined dressings are tissue biocompatible and do not induce inflammatory reactions after implantation

Table 1. Summarizing of application of different keratin dressing in an experimental wound model.

\begin{tabular}{|c|c|c|c|c|c|}
\hline \multirow{2}{*}{ Author } & \multirow{2}{*}{ Source of Keratin } & \multirow{2}{*}{$\begin{array}{l}\text { Type of Keratin } \\
\text { Wound Dressing }\end{array}$} & \multirow{2}{*}{ Healing Rate ( $p$-Value) } & \multicolumn{2}{|c|}{ Wound Status } \\
\hline & & & & Control Wound & Dressed Wound \\
\hline \multicolumn{6}{|c|}{ Experimental Studies } \\
\hline Lin et al. [22] & Human hair & $\begin{array}{l}\text { Keratin scaffold seeded } \\
\text { with hASCs }\end{array}$ & $p<0.05$ & $\begin{array}{c}\text { Injected with } 100 \\
\mu \mathrm{L} \text { of } \mathrm{PBS}+ \\
\text { semiocclusive } \\
\text { adhesive dressing }\end{array}$ & $\begin{array}{c}\text { Keratin scaffold seeded } \\
\text { with hASCs }+ \\
\text { semiocclusive } \\
\text { adhesive dressing }\end{array}$ \\
\hline Kim et al. [94] & Human hair & Keratin-based hydrogel & $p<0.05$ & PBS & $\begin{array}{c}\text { Keratin-based } \\
\text { hydrogels }(100 \mu \mathrm{L})\end{array}$ \\
\hline Li et al. [95] & Human hair & $\begin{array}{l}\text { Keratin hydrogel } \\
\text { conjugated insulin }\end{array}$ & $p<0.05$ & Untreated & $\begin{array}{l}\text { Treated with keratin, } \\
\text { insulin, and the } \\
\text { Ins-K hydrogels }\end{array}$ \\
\hline Poranki et al. [96] & Human hair & Keratin-hydrogel & $\begin{array}{c}\text { Mice chemical burns } \\
\text { model: at days } 4 \\
\text { through } 16 . p<0.05 \text {. } \\
\text { Swine thermal burn } \\
\text { model: at days } 3,6 \text {, and } \\
\text { 12. } p<0.05 \text {. }\end{array}$ & $\begin{array}{l}\text { Saline (occlusive } \\
\text { dressing) and } \\
\text { chitosan hydrogel }\end{array}$ & Keratin-hydrogel \\
\hline Gao et al. [97] & Human hair & $\begin{array}{c}\text { Recombinant human } \\
\text { hair keratin proteins } \\
\text { (RKNP37 and RKNP81) } \\
\text { and keratin } \\
\text { nanoparticles (KNP) }\end{array}$ & $p<0.05$ on day 7,14 . & Tegaderm film & $\begin{array}{c}0.500 \mathrm{mg} \text { of RKNP37, } \\
\text { RKNP81, or KNPs and } \\
\text { fixed with } \\
\text { Tegaderm film }\end{array}$ \\
\hline Chen et. al. [98] & Human hair & Keratin hydrogel & $\begin{array}{c}p<0.01 \text { (Keratin and } \\
\text { irradiated wound } \\
\text { versus exposed and } \\
\text { irradiated wound), } \\
p<0.05 \text { (Keratin and } \\
\text { irradiated wound } \\
\text { versus non-keratin } \\
\text { non-irradiated wound). }\end{array}$ & $\begin{array}{c}\text { Wounds exposed, } \\
\text { one exposed } \\
\text { and irradiated }\end{array}$ & Keratin hydrogel \\
\hline Konop et al. [8] & Mice fur & Keratin scaffolds (FKDP) & $p<0.05$ & No dressing & Keratin scaffolds \\
\hline
\end{tabular}


Table 1. Cont.

\begin{tabular}{|c|c|c|c|c|c|}
\hline \multirow{2}{*}{ Author } & \multirow{2}{*}{ Source of Keratin } & \multirow{2}{*}{$\begin{array}{l}\text { Type of Keratin } \\
\text { Wound Dressing }\end{array}$} & \multirow{2}{*}{ Healing Rate ( $p$-Value) } & \multicolumn{2}{|c|}{ Wound Status } \\
\hline & & & & Control Wound & Dressed Wound \\
\hline \multicolumn{6}{|c|}{ Experimental Studies } \\
\hline $\begin{array}{l}\text { Shanmugasundaram } \\
\text { et al. [99] }\end{array}$ & Chicken feather & $\begin{array}{l}\text { Chicken feather keratin } \\
(\text { CFK-NW), } \\
\text { keratin-sodium } \\
\text { alginate (CFK-SA-NW), } \\
\text { and keratin-chitosan } \\
(\text { CFK-CS-NW) }\end{array}$ & $\begin{array}{l}\text { No available } \\
\text { statistical analysis. }\end{array}$ & Nonwoven fabric & $\begin{array}{l}\text { Chicken feather keratin } \\
\text { (CFK-NW), } \\
\text { keratin-sodium } \\
\text { alginate (CFK-SA-NW), } \\
\text { and keratin-chitosan } \\
\text { (CFK-CS-NW) }\end{array}$ \\
\hline Vakilian et al. [100] & $\begin{array}{l}\text { Sneak shed skin } \\
\text { (Puff and } \\
\text { Cat Snakes) }\end{array}$ & $\begin{array}{l}\text { Puff snake shed skin }(\mathrm{P}) \\
\text { Cat snake shed skin }(\mathrm{C})\end{array}$ & $p<0.05$ & $\begin{array}{c}\text { No dressing } \\
\text { (negative control) } \\
\text { Solcoseryl ointment } \\
\text { (positive control) }\end{array}$ & $\begin{array}{l}\text { Puff snake shed skin }(\mathrm{P}) \\
\text { Cat snake shed skin }(\mathrm{C})\end{array}$ \\
\hline $\begin{array}{c}\text { Veerasubramanian } \\
\text { et al. [101] }\end{array}$ & Human hair & $\begin{array}{c}\text { Konjac } \\
\text { glucomannan-keratin } \\
\text { hydrogel scaffold } \\
\text { loaded with Avena } \\
\text { sativa extracts }\end{array}$ & $p<0.05$ & $\begin{array}{l}\text { Group I-control, } \\
\text { rats dressed in } \\
\text { non-medicated } \\
\text { cotton gauze }\end{array}$ & $\begin{array}{l}\text { Group II-rats dressed } \\
\text { with KGM + KER } \\
\text { scaffolds; and Group } \\
\text { III-rats dressed with } \\
\text { KGM + KER + OAT } \\
\text { scaffolds }\end{array}$ \\
\hline Ponrasu et al. [102] & Human hair & $\begin{array}{l}\text { Keratin hydrogel (KER) } \\
\text { supplemented with } \\
\text { Psyllium seed husk } \\
\text { (PSH) or Morin (MOR) }\end{array}$ & $p<0.05$ & $\begin{array}{l}\text { Group I-rats } \\
\text { dressed in } \\
\text { cotton gauze }\end{array}$ & $\begin{array}{l}\text { Group II-rats dressed } \\
\text { with PSH + KER } \\
\text { scaffolds; group III-rats } \\
\text { dressed with PSH + KER } \\
\text { + 0.50\% MOR scaffolds; } \\
\text { group IV-rats dressed } \\
\text { with PSH + KER + 1\% } \\
\text { MOR scaffolds }\end{array}$ \\
\hline Konop et al. [7] & Mice fur & Keratin scaffolds (FKDP) & $p<0.05$ & No dressing & Keratin scaffolds (FKDP) \\
\hline Konop et al. [10] & Mice fur & Keratin scaffolds (FKDP) & $p<0.05$ & No dressing & $\begin{array}{c}\text { Keratin scaffolds + } \\
\text { AgNP (FKDP-AgNP) }\end{array}$ \\
\hline Konop et al. [93] & Mice fur & Keratin scaffolds (FKDP) & $p<0.05$ & No dressing & $\begin{array}{l}\text { Keratin scaffolds }+0.1 \% \\
\text { Casomorphin }\end{array}$ \\
\hline
\end{tabular}

\section{Clinical Application of Keratin Biomaterial in Wound Healing}

In recent years, the use of new keratin-based wound dressings represents a novel approach to wound management in clinical practice (see Table 2). It should be mentioned that all examined keratin dressings were made from sheep's wool. Only a few studies described the application of a different form of keratin dressing in the treatment of chronic non-healing wounds or wounds observed in a patient with genetic disorders resulting from mutations in the genes encoding keratin [103]. Missense mutations in keratin 5 or keratin 14, highly expressed in the basal epidermis, cause the severe skin blistering disease epidermolysis bullosa (EB) in humans by rendering the keratin cytoskeleton sensitive to mechanical stress $[103,104]$. In addition, keratin-based dressing is a new therapeutic option for patients with autoimmune diseases, e.g., in different variants of epidermolysis bullosa $[105,106]$.

Than et al. [107], in their research, presented three patients with recalcitrant, venous, mixed venous, and arterial leg ulcers treated with keratin dressing: Keraderm (Blacksburg, Virginia), which is a robust matrix dressing derived from freeze-dried keratin protein, and Kerafoam (Onset Dermatologics, Cumberland, RI, USA), which is an absorbent polyurethane foam dressing with a laminated keratin film. It should be mentioned that, in the past, these patients have appropriate standard treatment. They observed that, after the application of keratin dressing, venous ulcer completely healed after 30 weeks. However, this study has some limitations, and the authors could not exactly determine the mechanism of wound improvement in these cases. They only suggested that improved healing can be associated with the application of keratin dressing. Moreover, these dressings were found to be comfortable and easy to use by the patients and nurses. 
In another study, Davidson et al. [108] attempted to determine if the experimental keratin dressing Keramatrix ${ }^{\circledR}$ (Keraplast, San Antonio, TX, USA) accelerates epithelialization rates during healing of partial-thickness wounds, relative to a Standard Care dressing (Algisite (Smith and Nephew, London)). They examined it, on two groups of patients, before and after 50 years old $(\mathrm{n}=26)$. They noticed that, in older patients ( $>50$ years), wounds healed more slowly. However, they observed that there was significantly more epithelialization after 7 days in wound parts treated with the keratin dressing compared with standard care. On the other hand, they observed that, in the younger patients, epithelization was almost complete at 7 days (median epithelialization percentage, $80 \%$ ). It should be mentioned that there was no significant difference in epithelization score between the keratin-treatment and control sides. This researcher suggested that the dressing may be clinically useful in similar situations where epithelialization may be delayed.

Kirsner et al. [106] used a keratin-based wound dressing in an infant patient with ESB. They applied KeragelT ${ }^{\circledR}$ (Keraplast, San Antonio, TX, USA) directly on the wound on the left hand and left foot and protected them with the same secondary dressings used as part of standard care. The right foot and hand healing continued with standard care and served as controls. Both dressings were changed 4 times per week. After 6 months of treatment, they observed faster-wound healing and decreased the number of blisters on the treated side ( 6 and 5 blister episodes on treated foot and hand, respectively, and 12 and 14 on control foot and hand, respectively) and decided to treat the control limbs. The authors hypothesized that keratin dressings enhance keratinocyte activity and accelerate epithelialization and wound closure. Moreover, keratin-based dressings improved quality of life and reduced the cost of care.

Than et al. [105] also examined Keragel ${ }^{\circledR}$ (Keraplast Technologies, LLC, San Antonio, TX, USA) as a wound dressing in an 11-year-old patient with diagnosed recessive dystrophic epidermolysis bullosa. The back of the neck was treated daily with $20 \mathrm{~g}$ of Keragel ${ }^{\circledR}$. After 3 months of treatment, a significant improvement was observed in the skin: the skin was much more robust, the incidence of blistering was much lower, and the wound had effectively healed. They observed a progressive, sustained improvement continued for the 12-month duration of the study. However, this study possesses some limitations: for example, lack of control side and the exact mechanism for the improvement is not fully understood and needs further study.

In addition, Dayner et al. [109] examined keratin gel (KeragelT ${ }^{\circledR}$, Keraplast Technologies, USA) in the management of wounds in 10 patients with different variants of epidermolysis bullosa (EB). The keratin gel was found tolerable and acceptable by $8 / 10$ patients; however, itching was noted in two patients with Junctional EB, generalized as severe, who discontinued use. The other patients reported reducing itching. Of the remaining eight, six continued long-term use of gel until the wound healed, and it was used for subsequent wounds that developed, as well. The localized epidermolysis bullosa simplex (EBS) patients discontinued use of the gel after no response was seen following four weeks of treatment. In conclusion, in the six patients in whom the keratin gel was effective, the healing times were faster, and healed skin was more resilient. The obtained results from this study are consistent with previous reports about healing improvement in patients with different variant bullosa diseases.

Another study, performed by Batzer et al. [110], describes the use of keratin-based wound products on refractory wounds. In this study, 45 chronic wounds of mixed etiologies presenting in 31 patients were treated with a solid keratin matrix $\left(K_{\text {Keramatrix }}^{\circledR}\right)$ and a liquid keratin gel (Keragel ${ }^{\circledR}$ ) wound dressing (Keraplast Technologies, San Antonio, TX, USA). They showed that topical keratin products resulted in improved healing in $82 \%$ of wounds that either healed $(64 \%)$ or reduced in size by $>50 \%$ during treatment. They also suggested that, in case of a wound infection, keratin treatment should be briefly interrupted, and antibacterial treatment should be started as soon as possible, and then application of keratin products should be restarted. 
Table 2. Clinical application of keratin biomaterial as a wound dressing.

\begin{tabular}{|c|c|c|c|c|c|}
\hline \multirow{2}{*}{ Author } & \multirow{2}{*}{$\begin{array}{l}\text { Source of } \\
\text { Keratin }\end{array}$} & \multirow{2}{*}{$\begin{array}{l}\text { Type of Keratin } \\
\text { Wound Dressing }\end{array}$} & \multirow{2}{*}{ Healing Rate ( $p$-Value) } & \multicolumn{2}{|c|}{ Wound Status } \\
\hline & & & & Control Wound & Dressed Wound \\
\hline Than et al. [105] & Sheep's wool & $\begin{array}{c}\text { Keragel }^{\circledR} \text { — keratin- } \\
\text { based hydrogel }\end{array}$ & No data & Lack of control site & Keragel $^{\circledR}$ \\
\hline Kirsner et al. [106] & Sheep's wool & $\begin{array}{l}\text { Keragel }^{\circledR} — \text { keratin- } \\
\text { enriched gel }\end{array}$ & $\begin{array}{l}\text { No data (healing } \\
\text { reduced from } 14 \text { to } \\
7 \text { days) }\end{array}$ & $\begin{array}{l}\text { Saline cleansing, soft } \\
\text { silicone-based, } \\
\text { nonadherent primary } \\
\text { dressing, also absorbent } \\
\text { foam dressing for the } \\
\text { feet, a tubular gauze } \\
\text { bandage wrap for hands }\end{array}$ & KeragelT $^{\circledR}$ \\
\hline Than et al. [107] & & $\begin{array}{c}\text { Robust matrix dressing } \\
\text { derived from freeze- } \\
\text { dried keratin protein }\end{array}$ & $\begin{array}{l}\text { No data (venous ulcer } \\
\text { completely healed after } \\
30 \text { weeks) }\end{array}$ & Lack of control site & $\begin{array}{l}\text { Keraderm } \\
\text { (Blacksburg, } \\
\text { Virginia) }\end{array}$ \\
\hline Davidson et al. [108] & Sheep's wool & $\begin{array}{c}\text { Keramatrix- } \\
\text { absorbable matrix rich } \\
\text { in keratin protein }\end{array}$ & No data & Alginate dressing & Keramatrix \\
\hline Dayner et al. [109] & Sheep's wool & $\begin{array}{l}\text { KeragelT }^{\circledR} \text { — keratin- } \\
\text { enriched gel }\end{array}$ & No data & Lack of control site & KeragelT $^{\circledR}$ \\
\hline Batzer et al. [110] & Sheep's wool & Keramatrix, Keragel ${ }^{\circledR}$ & No data & Lack of control site & $\begin{array}{c}\text { Keragel }^{\circledR}, \\
\text { Keramatrix }^{\prime}\end{array}$ \\
\hline Paulsen and Bygum [111] & Sheep's wool & Keragel $^{\circledR}$ & No data & Lack of control site & Keragel $^{\circledR}$ \\
\hline
\end{tabular}

Paulsen and Bygum [111] studied keratin gel (Keragel ${ }^{\circledR}$, Keraplast Technologies, LLC, Christchurch, New Zealand) as an adjuvant in the treatment of recalcitrant pyoderma gangrenosum ulcers in a 62-year-old woman. Earlier, the standard treatment (e.g., corticosteroids, cyclosporine, and infliximab) was unsuccessful. Treatment was initiated with the keratin gel as an alternative to intensifying immune suppression and was effective. In the next visit, after 9 days of treatment with the gel, the ulcers were diminished in size, and the systemic treatment with infliximab, corticosteroids, and methotrexate in tapering doses was continued, along with Kerage ${ }^{\circledR}$ as a topical treatment. In November 2015, after seven months of treatment, the ulcers were healed. Kerage ${ }^{\circledR}$ seems to be a safe and effective topical adjuvant in ulcers of immunological origin and is especially useful in promoting the last steps in the healing process. However, more controlled studies are needed to establish the usefulness of the keratin gel in the treatment of pyoderma gangrenosum ulcers.

\section{Concluding Remarks and Future Challenges}

Traditional wound dressings, such as natural or synthetic cotton wool, lint, bandages, gauzes, etc., with varying grades of absorbance capacity, have been used for wound management. From the general point of view, traditional dressings are indicated for clean and dry wounds with mild exudate levels or used as secondary dressings. Modern medicine is moving away from dry wound therapy. The traditional wound dressings are replaced by modern wound dressing with more advanced formulations to provide a moist environment to the wound and enhance healing.

Different types of keratin-based biomaterials have been developed over the last decade for biomedical applications, such as sponges, hydrogels, wound patches, films, and fibers. The different biomaterials could be applied, depending on the type of wound. The main function of this dressing is to create a moist environment and stimulate wound healing. Tissue engineering methods allow surface modification of biomaterials with antimicrobial or anti-inflammatory agents, to enhance tissue recovery. Another advantage of this material is that it is of natural origin, and some keratins are involved in skin morphogenesis. Keratin biomaterials are biocompatible, biodegradable, and support cell growth. As a part of the epithelial cytoskeleton, keratins are important for the mechanical stability and the integrity of epithelial cells and tissues. Regardless of the form of the keratin dressing, these 
biomaterials stimulate epithelization and possess hemostatic properties. Wounds treated by keratin dressing are characterized by a more ordered tissue structure, they are covered with the epidermis layer more quickly (the epidermis is thicker compared to control wounds), and they heal faster overall. The opportunity for modification of basic dressing with bioactive substances or antibiotics, which are slowly released from it is another advantage.

Although such promising results of experimental studies, we still do not know what molecular mechanisms are involved in the healing process. Some researchers suggested that the pathway of Akt-mTOR kinases participates in this process. Despite the promising results reported of the applications of these biomaterials, only a few of these progressed to clinical trials. However, these studies described single cases where keratin treatment was used. Multicenter studies of keratin dressings on a larger population of patients with wounds of various etiology are necessary to confirm that keratin dressing improves skin wound healing.

Author Contributions: M.K.-conceptualization, funding acquisition, writing-original draft, writing—review \& editing. M.R., A.D.—writing—original draft. All authors have read and agreed to the published version of the manuscript.

Funding: The authors disclosed receipt of the following financial support for the research, authorship, and/or publication of this article: This study was supported by Young Research Grant (1S7/2/M/MB/N/20/20:MAT) from Warsaw Medical University. This study was supported by Student Mini-grant (16/M/MG/N/21) from Warsaw Medical University.

Institutional Review Board Statement: Not applicable.

Informed Consent Statement: Not applicable.

Data Availability Statement: Not applicable.

Conflicts of Interest: The authors declare no conflict of interest.

\section{References}

1. Ehrlich, F.; Lachner, J.; Hermann, M.; Tschachler, E.; Eckhart, L. Convergent Evolution of Cysteine-Rich Keratins in Hard Skin Appendages of Terrestrial Vertebrates. Mol. Biol. Evol. 2020, 37, 982-993. [CrossRef] [PubMed]

2. Ehrlich, F.; Fischer, H.; Langbein, L.; Praetzel-Wunder, S.; Ebner, B.; Figlak, K.; Weissenbacher, A.; Sipos, W.; Tschachler, E.; Eckhart, L. Differential Evolution of the Epidermal Keratin Cytoskeleton in Terrestrial and Aquatic Mammals. Mol. Biol. Evol. 2019, 36, 328-340. [CrossRef] [PubMed]

3. Vasconcelos, A.; Cavaco-Paulo, A. The use of keratin in biomedical applications. Curr. Drug Targets 2013, 14, 612-619. [CrossRef]

4. Shah, A.; Tyagi, S.; Bharagava, R.N.; Belhaj, D.; Kumar, A.; Saxena, G.; Saratale, G.D.; Mulla, S.I. Keratin Production and Its Applications: Current and Future Perspective. In Keratin as a Protein Biopolymer: Extraction from Waste Biomass and Applications; Sharma, S., Kumar, A., Eds.; Springer International Publishing: Cham, Switzerland, 2019; pp. 19-34, ISBN 978-3-030-02901-2.

5. Shavandi, A.; Silva, T.H.; Bekhit, A.A.; Bekhit, A.E.-D.A. Keratin: Dissolution, extraction and biomedical application. Biomater. Sci. 2017, 5, 1699-1735. [CrossRef]

6. Gao, J.; Zhang, L.; Wei, Y.; Chen, T.; Ji, X.; Ye, K.; Yu, J.; Tang, B.; Sun, X.; Hu, J. Human hair keratins promote the regeneration of peripheral nerves in a rat sciatic nerve crush model. J. Mater. Sci. Mater. Med. 2019, 30, 82. [CrossRef] [PubMed]

7. Konop, M.; Czuwara, J.; Klodzinska, E.; Laskowska, A.K.; Zielenkiewicz, U.; Brzozowska, I.; Nabavi, S.M.; Rudnicka, L. Development of a novel keratin dressing which accelerates full-thickness skin wound healing in diabetic mice: In vitro and in vivo studies. J. Biomater. Appl. 2018, 33, 527-540. [CrossRef]

8. Konop, M.; Sulejczak, D.; Czuwara, J.; Kosson, P.; Misicka, A.; Lipkowski, A.W.; Rudnicka, L. The role of allogenic keratin-derived dressing in wound healing in a mouse model. Wound Repair Regen. 2017, 25, 62-74. [CrossRef]

9. Kurzepa, K.; Róycki, K.; Bochyñska, M.; Konop, M.; Urbanczyk-Lipkowska, Z.; Lipkowski, A.W. Molecular scaffolds for three-dimensional cell and tissue cultures. Polimery 2013, 58, 663-669. [CrossRef]

10. Konop, M.; Czuwara, J.; Kłodzińska, E.; Laskowska, A.K.; Sulejczak, D.; Damps, T.; Zielenkiewicz, U.; Brzozowska, I.; Sureda, A.; Kowalkowski, T.; et al. Evaluation of keratin biomaterial containing silver nanoparticles as a potential wound dressing in full-thickness skin wound model in diabetic mice. J. Tissue Eng. Regen. Med. 2020, 14, 334-346. [CrossRef]

11. Nasipuri, P.; Herschend, J.; Brejnrod, A.D.; Madsen, J.S.; Espersen, R.; Svensson, B.; Burmølle, M.; Jacquiod, S.; Sørensen, S.J. Community-intrinsic properties enhance keratin degradation from bacterial consortia. PLoS ONE 2020, 15, e0228108. [CrossRef] [PubMed]

12. Negut, I.; Grumezescu, V.; Grumezescu, A.M. Treatment strategies for infected wounds. Molecules 2018, 23, 2392. [CrossRef]

13. Turner, T.D. The development of wound managment products. Wounds 1989, 1, 155-171. 
14. Swenty, C.F. Principles to Guide Your Dressing Choice. J. Nurse Pract. 2016, 12, e125-e127. [CrossRef]

15. Ousey, K.; Cutting, K.F.; Rogers, A.A.; Rippon, M.G. The importance of hydration in wound healing: Reinvigorating the clinical perspective. J. Wound Care 2016, 25, 122-130. [CrossRef] [PubMed]

16. Dhivya, S.; Padma, V.V.; Santhini, E. Wound dressings-A review. BioMedicine 2015, 5, 22. [CrossRef]

17. Qiu, Y.; Qiu, L.; Cui, J.; Wei, Q. Bacterial cellulose and bacterial cellulose-vaccarin membranes for wound healing. Mater. Sci. Eng. C 2016, 59, 303-309. [CrossRef]

18. Fan, L.; Yang, H.; Yang, J.; Peng, M.; Hu, J. Preparation and characterization of chitosan/gelatin/PVA hydrogel for wound dressings. Carbohydr. Polym. 2016, 146, 427-434. [CrossRef] [PubMed]

19. Dabiri, G.; Damstetter, E.; Phillips, T. Choosing a Wound Dressing Based on Common Wound Characteristics. Adv. Wound Care 2016, 5, 32-41. [CrossRef] [PubMed]

20. Ye, S.; Jiang, L.; Wu, J.; Su, C.; Huang, C.; Liu, X.; Shao, W. Flexible Amoxicillin-Grafted Bacterial Cellulose Sponges for Wound Dressing: In Vitro and in Vivo Evaluation. ACS Appl. Mater. Interfaces 2018, 10, 5862-5870. [CrossRef]

21. RǍdulescu, M.; Holban, A.M.; MogoantǍ, L.; BǍlşeanu, T.A.; Mogoşanu, G.D.; Savu, D.; Popescu, R.C.; Fuf Grumezescu, A.M.; Bezirtzoglou, E.; et al. Fabrication, characterization, and evaluation of bionanocomposites based on natural polymers and antibiotics for wound healing applications. Molecules 2016, 21, 761. [CrossRef]

22. Lin, C.W.; Chen, Y.K.; Tang, K.C.; Yang, K.C.; Cheng, N.C.; Yu, J. Keratin scaffolds with human adipose stem cells: Physical and biological effects toward wound healing. J. Tissue Eng. Regen. Med. 2019, 13, 1044-1058. [CrossRef]

23. Roy, D.C.; Tomblyn, S.; Isaac, K.M.; Kowalczewski, C.J.; Burmeister, D.M.; Burnett, L.R.; Christy, R.J. Ciprofloxacin-loaded keratin hydrogels reduce infection and support healing in a porcine partial-thickness thermal burn. Wound Repair Regen. 2016, 24, 657-668. [CrossRef]

24. Gupta, A.; Briffa, S.M.; Swingler, S.; Gibson, H.; Kannappan, V.; Adamus, G.; Kowalczuk, M.; Martin, C.; Radecka, I. Synthesis of Silver Nanoparticles Using Curcumin-Cyclodextrins Loaded into Bacterial Cellulose-Based Hydrogels for Wound Dressing Applications. Biomacromolecules 2020, 21, 1802-1811. [CrossRef] [PubMed]

25. Pang, S.; Gao, Y.; Wang, F.; Wang, Y.; Cao, M.; Zhang, W.; Liang, Y.; Song, M.; Jiang, G. Toxicity of silver nanoparticles on wound healing: A case study of zebrafish fin regeneration model. Sci. Total Environ. 2020, 717, 137178. [CrossRef]

26. Boer, M.; Duchnik, E.; Maleszka, R.; Marchlewicz, M. Structural and biophysical characteristics of human skin in maintaining proper epidermal barrier function. Postep. Dermatol. Alergol. 2016, 33, 1-5. [CrossRef]

27. Lai-Cheong, J.E.; McGrath, J.A. Structure and function of skin, hair and nails. Medicine 2017, 45, 347-351. [CrossRef]

28. Joffe, R.; Plaza, J.A.; Kajoian, A. Tip Chapter: Histology and Physiology of the Skin. In Minimally Invasive Aesthetic Procedures: A Guide for Dermatologists and Plastic Surgeons; Da Costa, A., Ed.; Springer International Publishing: Cham, Switzerland, 2020; pp. 179-192, ISBN 978-3-319-78265-2.

29. Gantwerker, E.A.; Hom, D.B. Skin: Histology and physiology of wound healing. Clin. Plast. Surg. 2012, 39, 85-97. [CrossRef] [PubMed]

30. Fuchs, E. Epithelial Skin Biology. Three Decades of Developmental Biology, a Hundred Questions Answered and a Thousand New Ones to Address. In Current Topics in Developmental Biology; Elsevier: Amsterdam, The Netherlands, 2016, ISBN 9780128029565.

31. Baroni, A.; Buommino, E.; De Gregorio, V.; Ruocco, E.; Ruocco, V.; Wolf, R. Structure and function of the epidermis related to barrier properties. Clin. Dermatol. 2012, 30, 257-262. [CrossRef]

32. McMillan, J.R.; Akiyama, M.; Shimizu, H. Epidermal basement membrane zone components: Ultrastructural distribution and molecular interactions. J. Dermatol. Sci. 2003, 31, 169-177. [CrossRef]

33. Bruckner-Tuderman, L.; Has, C. Disorders of the cutaneous basement membrane zone-The paradigm of epidermolysis bullosa. Matrix Biol. 2014, 33, 29-34. [CrossRef]

34. Chan, L.S. Human skin basement membrane in health and in autoimmune diseases. Front. Biosci. 1997, 2, 343-352. [CrossRef] [PubMed]

35. Lai-Cheong, J.E.; Arita, K.; McGrath, J.A. Genetic diseases of junctions. J. Investig. Dermatol. 2007, 127, 2713-2725. [CrossRef] [PubMed]

36. Uitto, J.; Has, C.; Vahidnezhad, H.; Youssefian, L.; Bruckner-Tuderman, L. Molecular pathology of the basement membrane zone in heritable blistering diseases: The paradigm of epidermolysis bullosa. Matrix Biol. 2017, 57, 76-85. [CrossRef]

37. Daniel, B.S.; Murrell, D.F. Review of autoimmune blistering diseases: The Pemphigoid diseases. J. Eur. Acad. Dermatol. Venereol. 2019, 33, 1685-1694. [CrossRef]

38. Didona, D.; Maglie, R.; Eming, R.; Hertl, M. Pemphigus: Current and future therapeutic strategies. Front. Immunol. 2019, 10, 1418. [CrossRef] [PubMed]

39. Kolarsick, P.A.J.; Kolarsick, M.A.; Goodwin, C. Anatomy and Physiology of the Skin. J. Dermatol. Nurses' Assoc. $2011,3,366$. [CrossRef]

40. Rippa, A.L.; Kalabusheva, E.P.; Vorotelyak, E.A. Regeneration of Dermis: Scarring and Cells Involved. Cells 2019, 8, 607. [CrossRef]

41. Woodley, D.T. Distinct Fibroblasts in the Papillary and Reticular Dermis: Implications for Wound Healing. Dermatol. Clin. 2017, 35, 95-100. [CrossRef] 
42. Dehdashtian, A.; Stringer, T.P.; Warren, A.J.; Mu, E.W.; Amirlak, B.; Shahabi, L. Anatomy and Physiology of the Skin. In Melanoma: A Modern Multidisciplinary Approach; Riker, A.I., Ed.; Springer International Publishing: Cham, Switzerland, 2018; pp. 15-26, ISBN 978-3-319-78310-9.

43. Singh, V.; Wang, S.; Ng, K.W. 2.25 Keratin as a Biomaterial. In Comprehensive Biomaterials II; Ducheyne, P., Ed.; Elsevier: Oxford, UK, 2017; pp. 542-557, ISBN 978-0-08-100692-4.

44. Pan, X.; Hobbs, R.P.; Coulombe, P.A. The expanding significance of keratin intermediate filaments in normal and diseased epithelia. Curr. Opin. Cell Biol. 2013, 25, 47-56. [CrossRef]

45. Heid, H.W.; Moll, I.; Franke, W.W. Patterns of expression of trichocytic and epithelial cytokeratins in mammalian tissues. I. Human and bovine hair follicles. Differentiation 1988, 37, 137-157. [CrossRef]

46. Heid, H.W.; Werner, E.; Franke, W.W. The complement of native $\alpha$-keratin polypeptides of hair-forming cells: A subset of eight polypeptides that differ from epithelial cytokeratins. Differentiation 1986, 32, 101-119. [CrossRef] [PubMed]

47. Kitahara, T.; Ogawa, H. Coexpression of keratins characteristic of skin and hair differentiation in nail cells. J. Investig. Dermatol. 1993, 100, 171-175. [CrossRef] [PubMed]

48. Jacob, J.T.; Coulombe, P.A.; Kwan, R.; Omary, M.B. Types I and II keratin intermediate filaments. Cold Spring Harb. Perspect. Biol. 2018, 10, a018275. [CrossRef] [PubMed]

49. Oshima, R.G. Apoptosis and keratin intermediate filaments. Cell Death Differ. 2002, 9, 486-492. [CrossRef] [PubMed]

50. Zhang, X.; Yin, M.; Zhang, L.J. Keratin 6, 16 and 17-Critical Barrier Alarmin Molecules in Skin Wounds and Psoriasis. Cells 2019, 8, 807. [CrossRef] [PubMed]

51. Hobbs, R.P.; Lessard, J.C.; Coulombe, P.A. Keratin intermediate filament proteins-Novel regulators of inflammation and immunity in skin. J. Cell Sci. 2012, 125, 5257-5258. [CrossRef]

52. Wong, P.; Colucci-Guyon, E.; Takahashi, K.; Gu, C.; Babinet, C.; Coulombe, P.A. Introducing a null mutation in the mouse K6 $\alpha$ and K6 3 genes reveals their essential structural role in the oral mucosa. J. Cell Biol. 2000, 150, 921-928. [CrossRef]

53. Wong, P.; Coulombe, P.A. Loss of keratin $6(\mathrm{~K} 6)$ proteins reveals a function for intermediate filaments during wound repair. J. Cell Biol. 2003, 276, 75-81. [CrossRef]

54. Rotty, J.D.; Coulombe, P.A. A wound-induced keratin inhibits Src activity during keratinocyte migration and tissue repair. J. Cell Biol. 2012, 197, 381-389. [CrossRef]

55. Kim, S.; Wong, P.; Coulombe, P.A. A keratin cytoskeletal protein regulates protein synthesis and epithelial cell growth. Nature 2006, 441, 362-365. [CrossRef]

56. Yang, L.; Jin, L.; Ke, Y.; Fan, X.; Zhang, T.; Zhang, C.; Bian, H.; Wang, G. E3 ligase Trim21 ubiquitylates and stabilizes Keratin 17 to induce STAT3 nuclear transport in psoriasis. J. Investig. Dermatol. 2018, 138, 2568-2577. [CrossRef] [PubMed]

57. Krzyszczyk, P.; Schloss, R.; Palmer, A.; Berthiaume, F. The role of macrophages in acute and chronic wound healing and interventions to promote pro-wound healing phenotypes. Front. Physiol. 2018, 9, 419. [CrossRef] [PubMed]

58. Werner, S.; Keller, L.; Pantel, K. Epithelial keratins: Biology and implications as diagnostic markers for liquid biopsies. Mol. Asp. Med. 2020, 72, 100817. [CrossRef]

59. Kakkar, P.; Madhan, B. Fabrication of keratin-silica hydrogel for biomedical applications. Mater. Sci. Eng. C 2016, 66, 178-184. [CrossRef]

60. Husain, M.S.B.; Gupta, A.; Alashwal, B.Y. Development of keratin based hydrogels for biomedical applications. In IOP Conference Series: Materials Science and Engineering; IOP Publishing: Bristol, UK, 2019; Volume 702, p. 012031. [CrossRef]

61. Morais, J.M.; Papadimitrakopoulos, F.; Burgess, D.J. Biomaterials/tissue interactions: Possible solutions to overcome foreign body response. AAPS J. 2010, 12, 188-196. [CrossRef]

62. Reichl, S. Films based on human hair keratin as substrates for cell culture and tissue engineering. Biomaterials 2009, 30, 6854-6866. [CrossRef]

63. Zafar, K.; Jamal, S.; Ghafoor, R. Bio-active cements-Mineral Trioxide Aggregate based calcium silicate materials: A narrative review. J. Pak. Med. Assoc. 2020, 70, 497-504. [CrossRef]

64. Bochynska-Czyz, M.; Redkiewicz, P.; Kozlowska, H.; Matalinska, J.; Konop, M.; Kosson, P. Can keratin scaffolds be used for creating three-dimensional cell cultures? Open Med. 2020, 15, 249-253. [CrossRef] [PubMed]

65. Yamauchi, K.; Maniwa, M.; Mori, T. Cultivation of fibroblast cells on keratin-coated substrata. J. Biomater. Sci. Polym. Ed. 1998, 9 , 259-270. [CrossRef]

66. Park, M.; Shin, H.K.; Kim, B.-S.; Kim, M.J.; Kim, I.-S.; Park, B.-Y.; Kim, H.-Y. Effect of discarded keratin-based biocomposite hydrogels on the wound healing process in vivo. Mater. Sci. Eng. C 2015, 55, 88-94. [CrossRef]

67. Sadeghi, S.; Nourmohammadi, J.; Ghaee, A.; Soleimani, N. Carboxymethyl cellulose-human hair keratin hydrogel with controlled clindamycin release as antibacterial wound dressing. Int. J. Biol. Macromol. 2020, 147, 1239-1247. [CrossRef]

68. Prati, C.; Gandolfi, M.G. Calcium silicate bioactive cements: Biological perspectives and clinical applications. Dent. Mater. 2015, 31, 351-370. [CrossRef]

69. Bernard, M.; Jubeli, E.; Pungente, M.D.; Yagoubi, N. Biocompatibility of polymer-based biomaterials and medical devicesregulations: In vitro screening and risk-management. Biomater. Sci. 2018, 6, 2025-2053. [CrossRef]

70. Peplow, P.V.; Dias, G.J. A study of the relationship between mass and physical strength of keratin bars in vivo. J. Mater. Sci. Mater. Med. 2004, 15, 1217-1220. [CrossRef] 
71. Patrucco, A.; Visai, L.; Fassina, L.; Magenes, G.; Tonin, C. Keratin-based matrices from wool fibers and human hair. In Materials for Biomedical Engineering: Biopolymer Fibers; Elsevier: Amsterdam, The Netherlands, 2019, ISBN 9780128168721.

72. Placone, J.K.; Navarro, J.; Laslo, G.W.; Lerman, M.J.; Gabard, A.R.; Herendeen, G.J.; Falco, E.E.; Tomblyn, S.; Burnett, L.; Fisher, J.P. Development and Characterization of a 3D Printed, Keratin-Based Hydrogel. Ann. Biomed. Eng. 2017, 45, 237-248. [CrossRef] [PubMed]

73. Khajavi, R.; Rahimi, M.K.; Abbasipour, M.; Brendjchi, A.H. Antibacterial nanofibrous scaffolds with lowered cytotoxicity using keratin extracted from quail feathers. J. Bioact. Compat. Polym. 2016, 31, 60-71. [CrossRef]

74. Amajuoyi, J.N.; Ilomuanya, M.O.; Asantewaa-Osei, Y.; Azubuike, C.P.; Adeosun, S.O.; Igwilo, C.I. Development of electrospun keratin/coenzyme Q10/poly vinyl alcohol nanofibrous scaffold containing mupirocin as potential dressing for infected wounds. Future J. Pharm. Sci. 2020, 6, 25. [CrossRef]

75. He, M.; Chen, M.; Dou, Y.; Ding, J.; Yue, H.; Yin, G.; Chen, X.; Cui, Y. Electrospun Silver Nanoparticles-Embedded Feather Keratin/Poly(vinyl alcohol)/Poly(ethylene oxide) Antibacterial Composite Nanofibers. Polymers 2020, 12, 305. [CrossRef]

76. Sundaram, M.; Legadevi, R.; Afrin Banu, N.; Gayathri, V.; Palanisammy, A. A study on anti bacterial activity of keratin nanoparticles from chicken feather waste against Staphylococcus aureus (Bovine Mastitis Bacteria) and its anti oxidant activity. Eur. J. Biotechnol. Biosci. 2015, 3, 1-5.

77. Gu, L.-H.; Coulombe, P.A. Keratin function in skin epithelia: A broadening palette with surprising shades. Curr. Opin. Cell Biol. 2007, 19, 13-23. [CrossRef]

78. Coulombe, P.A.; Kerns, M.L.; Fuchs, E. Epidermolysis bullosa simplex: A paradigm for disorders of tissue fragility. J. Clin. Investig. 2009, 119, 1784-1793. [CrossRef] [PubMed]

79. Uttam, J.; Hutton, E.; Coulombe, P.A.; Anton-Lamprecht, I.; Yu, Q.C.; Gedde-Dahl, T.J.; Fine, J.D.; Fuchs, E. The genetic basis of epidermolysis bullosa simplex with mottled pigmentation. Proc. Natl. Acad. Sci. USA 1996, 93, 9079-9084. [CrossRef]

80. Betz, R.C.; Planko, L.; Eigelshoven, S.; Hanneken, S.; Pasternack, S.M.; Bussow, H.; Van Den Bogaert, K.; Wenzel, J.; Braun-Falco, M.; Rutten, A.; et al. Loss-of-function mutations in the keratin 5 gene lead to Dowling-Degos disease. Am. J. Hum. Genet. 2006, 78, 510-519. [CrossRef] [PubMed]

81. Lugassy, J.; Itin, P.; Ishida-Yamamoto, A.; Holland, K.; Huson, S.; Geiger, D.; Hennies, H.C.; Indelman, M.; Bercovich, D.; Uitto, J.; et al. Naegeli-Franceschetti-Jadassohn syndrome and dermatopathia pigmentosa reticularis: Two allelic ectodermal dysplasias caused by dominant mutations in KRT14. Am. J. Hum. Genet. 2006, 79, 724-730. [CrossRef] [PubMed]

82. Fitch, K.R.; McGowan, K.A.; van Raamsdonk, C.D.; Fuchs, H.; Lee, D.; Puech, A.; Hérault, Y.; Threadgill, D.W.; Hrabé de Angelis, M.; Barsh, G.S. Genetics of dark skin in mice. Genes Dev. 2003, 17, 214-228. [CrossRef]

83. McGowan, K.A.; Aradhya, S.; Fuchs, H.; de Angelis, M.H.; Barsh, G.S. A mouse keratin 1 mutation causes dark skin and epidermolytic hyperkeratosis. J. Investig. Dermatol. 2006, 126, 1013-1016. [CrossRef]

84. McGowan, K.A.; Fuchs, H.; Hrabé de Angelis, M.; Barsh, G.S. Identification of a Keratin 4 mutation in a chemically induced mouse mutant that models white sponge nevus. J. Investig. Dermatol. 2007, 127, 60-64. [CrossRef] [PubMed]

85. Moll, R.; Franke, W.W.; Schiller, D.L.; Geiger, B.; Krepler, R. The catalog of human cytokeratins: Patterns of expression in normal epithelia, tumors and cultured cells. Cell 1982, 31, 11-24. [CrossRef]

86. Omary, M.B.; Coulombe, P.A.; McLean, W.H.I. Intermediate filament proteins and their associated diseases. N. Engl. J. Med. 2004, 351, 2087-2100. [CrossRef]

87. Loan, F.; Cassidy, S.; Marsh, C.; Simcock, J. Keratin-based products for effective wound care management in superficial and partial thickness burns injuries. Burns 2016, 42, 541-547. [CrossRef]

88. de Chalain, T.M.; Tang, C.; Thomson, H.G. Burn area color changes after superficial burns in childhood: Can they be predicted? J. Burn Care Rehabil. 1998, 19, 39-49. [CrossRef] [PubMed]

89. Bhawan, J.; Whren, K.; Panova, I.; Yaar, M. Keratin 16 expression in epidermal melanocytes of normal human skin. Am. J. Dermatopathol. 2005, 27, 476-481. [CrossRef]

90. Derakhshandeh, H.; Kashaf, S.S.; Aghabaglou, F.; Ghanavati, I.O.; Tamayol, A. Smart Bandages: The Future of Wound Care. Trends Biotechnol. 2018, 36, 1259-1274. [CrossRef] [PubMed]

91. Rajabi, M.; Ali, A.; McConnell, M.; Cabral, J. Keratinous materials: Structures and functions in biomedical applications. Mater. Sci. Eng. C 2020, 110, 110612. [CrossRef] [PubMed]

92. Feroz, S.; Muhammad, N.; Ranayake, J.; Dias, G. Keratin-Based materials for biomedical applications. Bioact. Mater. 2020, 5, 496-509. [CrossRef]

93. Konop, M.; Laskowska, A.K.; Rybka, M.; Kłodzińska, E.; Sulejczak, D.; Schwartz, R.A.; Czuwara, J. Keratin Scaffolds Containing Casomorphin Stimulate Macrophage Infiltration and Accelerate Full-Thickness Cutaneous Wound Healing in Diabetic Mice. Molecules 2021, 26, 2554. [CrossRef] [PubMed]

94. Kim, S.Y.; Park, B.J.; Lee, Y.; Park, N.J.; Park, K.M.; Hwang, Y.S.; Park, K.D. Human hair keratin-based hydrogels as dynamic matrices for facilitating wound healing. J. Ind. Eng. Chem. 2019, 73, 142-151. [CrossRef]

95. Li, W.; Gao, F.; Kan, J.; Deng, J.; Wang, B.; Hao, S. Synthesis and fabrication of a keratin-conjugated insulin hydrogel for the enhancement of wound healing. Colloids Surf. B Biointerfaces 2019, 175, 436-444. [CrossRef]

96. Poranki, D.; Whitener, W.; Howse, S.; Mesen, T.; Howse, E.; Burnell, J.; Greengauz-Roberts, O.; Molnar, J.; Van Dyke, M. Evaluation of skin regeneration after burns in vivo and rescue of cells after thermal stress in vitro following treatment with a keratin biomaterial. J. Biomater. Appl. 2014, 29, 26-35. [CrossRef] [PubMed] 
97. Gao, F.; Li, W.; Deng, J.; Kan, J.; Guo, T.; Wang, B.; Hao, S. Recombinant Human Hair Keratin Nanoparticles Accelerate Dermal Wound Healing. ACS Appl. Mater. Interfaces 2019, 11, 18681-18690. [CrossRef]

98. Chen, X.; Zhai, D.; Wang, B.; Hao, S.; Song, J.; Peng, Z. Hair keratin promotes wound healing in rats with combined radiationwound injury. J. Mater. Sci. Mater. Med. 2020, 31, 28. [CrossRef]

99. Shanmugasundaram, O.L.; Syed Zameer Ahmed, K.; Sujatha, K.; Ponnmurugan, P.; Srivastava, A.; Ramesh, R.; Sukumar, R.; Elanithi, K. Fabrication and characterization of chicken feather keratin/polysaccharides blended polymer coated nonwoven dressing materials for wound healing applications. Mater. Sci. Eng. C 2018, 92, 26-33. [CrossRef]

100. Vakilian, S.; Jamshidi-adegani, F.; Al-Shidhani, S.; Anwar, M.U.; Al-Harrasi, R.; Al-Wahaibi, N.; Qureshi, A.; Alyaqoobi, S.; Al-Amri, I.; Al-Harrasi, A.; et al. A Keratin-based biomaterial as a promising dresser for skin wound healing. Wound Med. 2019, 25, 100155. [CrossRef]

101. Veerasubramanian, P.K.; Thangavel, P.; Kannan, R.; Chakraborty, S.; Ramachandran, B.; Suguna, L.; Muthuvijayan, V. Corrigendum to "An investigation of konjac glucomannan-keratin hydrogel scaffold loaded with Avena sativa extracts for diabetic wound healing" [Colloids Surf. B Biointerfaces 165 (2018) 92-102] (S0927776518300973) (10.1016/j.colsurfb.2018.02.022). Colloids Surf. B Biointerfaces 2018, 171, 319. [CrossRef] [PubMed]

102. Ponrasu, T.; Veerasubramanian, P.K.; Kannan, R.; Gopika, S.; Suguna, L.; Muthuvijayan, V. Morin incorporated polysaccharideprotein (psyllium-keratin) hydrogel scaffolds accelerate diabetic wound healing in Wistar rats. RSC Adv. 2018, 8, $2305-2314$. [CrossRef]

103. Vahidnezhad, H.; Youssefian, L.; Saeidian, A.H.; Mozafari, N.; Barzegar, M.; Sotoudeh, S.; Daneshpazhooh, M.; Isaian, A.; Zeinali, S.; Uitto, J. KRT5 and KRT14 Mutations in Epidermolysis Bullosa Simplex with Phenotypic Heterogeneity, and Evidence of Semidominant Inheritance in a Multiplex Family. J. Investig. Dermatol. 2016, 136, 1897-1901. [CrossRef] [PubMed]

104. Khani, P.; Ghazi, F.; Zekri, A.; Nasri, F.; Behrangi, E.; Aghdam, A.M.; Mirzaei, H. Keratins and epidermolysis bullosa simplex. J. Cell. Physiol. 2018, 234, 289-297. [CrossRef]

105. Than, M.P.; Smith, R.A.; Cassidy, S.; Kelly, R.; Marsh, C.; Maderal, A.; Kirsner, R.S. Use of a keratin-based hydrogel in the management of recessive dystrophic epidermolysis bullosa. J. Dermatol. Treat. 2013, 24, 290-291. [CrossRef]

106. Kirsner, R.S.; Cassidy, S.; Marsh, C.; Vivas, A.; Kelly, R.J. Use of a Keratin-Based Wound Dressing in the Management of Wounds in a Patient with Recessive Dystrophic Epidermolysis Bullosa. Adv. Skin Wound Care 2012, 25, 400-403. [CrossRef] [PubMed]

107. Than, M.P.; Smith, R.A.; Hammond, C.; Kelly, R.; Marsh, C.; Maderal, A.D.; Kirsner, R.S. Keratin-based Wound Care Products for Treatment of Resistant Vascular Wounds. J. Clin. Aesthet. Dermatol. 2012, 5, 31-35.

108. Davidson, A.; Jina, N.H.; Marsh, C.; Than, M.; Simcock, J.W. Do functional keratin dressings accelerate epithelialization in human partial thickness wounds? A randomized controlled trial on skin graft donor sites. Eplasty 2013, 13, e45. [PubMed]

109. Denyer, J.; Marsh, C.; Kirsner, R.S. Keratin gel in the management of Epidermolysis bullosa. J. Wound Care 2015, $24,446-450$. [CrossRef] [PubMed]

110. Batzer, A.T.; Marsh, C.; Kirsner, R.S. The use of keratin-based wound products on refractory wounds. Int. Wound J. 2016, 13, 110-115. [CrossRef]

111. Paulsen, E.; Bygum, A. Keratin gel as an adjuvant in the treatment of recalcitrant pyoderma gangrenosum ulcers: A case report. Acta Derm. Venereol. 2019, 99, 234-235. [CrossRef] [PubMed] 